\title{
Cross Cultural Interpretation and Valuing of Northwest Coast Art by Natives and Non-Native Americans
}

\author{
Nancy Schien Parks
}

\begin{abstract}
It is essential to bear in mind the twotold source of artistic effect, the one based on form alone, the other on idea associated with form. Otherwise the theory of art will be one-sided.
\end{abstract}

(Boaz, 1927 p. 13)

Changing demographics within the United States called for economic, social, political, and educational change during the turbulent 60 s which resulted in a renewed look at diversity. Changes in educational institutions in respect to multicultural initiatives, however, only began to have effect in the 1980s. As noted by Sahasrabudhe (1992) " 'Multiculturalism was first adequately defined only around 1979 ' by James Banks" (p.42). In the past two decades of the 1980 s and the $1990 \mathrm{~s}$, art educators have become increasingly involved in discourse about multicultural education; they have been examining curriculum, instruction. and assessment as they relate to art and culture (Chalmers, 1992; Hart, 1991; McFee, 1991, Smith, 1994, Stuhr, 1991; Wasson, Stuhr, and Petrovich-Mwaniki, 1990, Zimmerman, 1990), although a few were also involved in inquiring into these issues in the 1960 s and 1970 s.

This study explores how members of certain subcultures view and value their own art as well as how members outside their cultural groups value art work produced within these same sub-cultural groups. In a related study, Neperud and Stuhr (1993) looked at cross-cultural valuing among Native Americans and nonNative Americans. The purpose of their study was to determine how Native Americans and non-Native Americans valued a selected range of art works made by Native Americans living in the state of Wisconsin. They also tried to determine if differences in valuing existed between Native and non-Native Americans. The researchers categorized art made by Native Americans living in Wisconsin as (1) traditional - works that utilized historical torms and materials, (2) transitional -works that utilized traditional forms or combinations of traditional forms with contemporary materials experienced through contact with European or the dominant American culture, and (3) transformative - work using contemporary forms and materials that may contain Native American subject matter. The researchers then looked at responses of Chippewas. Menominees, and nonNative Americans who ranged from middle school to college level, to art work made by Native Americans that had been classitied into one of the three categories.

Their findings indicated that Native Americans in the study assigned the Native American art categorized as transitional with the highest ratings and Native American art classified as transformative with the lowest ratings. The researchers anticipated going into their study that Native Americans' adherence to traditional values would result in traditional forms rated the highest, but this was not the

Marilyn Zurmuehlen's Working Papers In Art Education 1996-1997 
case. The researchers speculated that this finding may be due to (1) the participants' education and exposure to Western conceptions of art, (2) the nature of cultural transmission of ceremonial and spiritual cultural art forms within Native American culture which is selective, or (3) understanding by participants that the art forms are not recognized as art within the Native American culture.

The non Native Americans subjects gave art classified as traditional highest ratings and art categorized as transformative lowest ratings. All of the non-Native American ratings of Native American art were lower than the responses made by Native Americans to Native American art. Although both groups rated transitional art as high. Native Americans rated transitional art much higher than did the non-Native Americans. The results of this study indicate that ethnic values are not static and unchanging, but fluid and dynamic.

Another area discussed within this discourse about multicultural education has been the role of the art teacher in helping students understand cultural diversity in the arts and the art contributions of all members of a multicultural society. In a discussion about issues and problems in multicultural art education, Clark (1990) used the teaching of African art to identify prerequisites for educators in order for successful teaching to occur, such as acquiring specific knowledge about a culture and its forms. He stated:

To teach effectively about the Yoruba culture or about African tribal art in general requires, before all else that a teacher leam as much as possible about the interactions of European colonists and African tribespersons. the roles of tribal arts in local African cultures, the transformations of ethnographic objects into "fine art" objects by western cultures, and as much as possible of the social and cultural history of the people who originally made and used the objects being studied. (p.13)

Clark further stated that all citizens are exposed to a variety of cultures and that even though parents and teachers can't control children's reactions, they can 'engineer' more positive than negative reactions to art that originates in cultures with which students are not familiar.

\section{Research Question}

Recognizing the critical role that art teachers play in helping children engage and understand art from within and outside the United States, and the fact that the majority of art teachers are white females, 1 decided to examine crosscultural interpretations and valuing of art from the Northwest Coast. Specifically, 1 focused on how Northwest Coast two-dimensional surface decoration that is painted, carved, or a combination of these two techniques, was interpreted and valued by a Euro-American art teacher and three white, sixth-grade students. A Northwest Coast Native American's interpretations c similar decoration was also examined to determine if differences between his interpretations with those of the art teacher and these students. A pilot study for this research was conducted during the Fall of 1995 . The setting for this pilot study was a rural, midwestern elementary school with a total population of approximately four hundred and

Marilyn Zurmuehlen's Working Papers In Art Education 1996-1997 
twenty-five, predominately white students, in grades K-6. The art teacher in this study has been an art instructor for over twelve years and the art teacher for students participating in this study for five and a half years. This is the second time the art teacher has presented a unit of study on Northwest Coast art that emphasized the iconography found in this culture. The unit of study stretched over a four week period, with one week lost due to a staff development day.

According to Hamblen (1990), postmodern critiques of what she refers to as the 'cash aesthetic,' a singular aesthetic value promoted in educational literature and rooted in values of Modernity, have questioned whether art education should be narrowly focused on a Western "fine art" aesthetic point of view. Noting Blandy and Congdon's (1989) earlier criticisms, Hamblen stated:

Folk, domestic, hiddenstream, collaborative, commercial, popular, confrontational, feminist arts - to mention a few - and the broad categories of multicultural and cross-cultural arts are absent or given token representation in most art education textbooks and state curriculum guidelines. ( $p .221)$

When attempts are made by art teachers outside a sub-culture to present cross cultural art forms to their students, (1) How do they represent the art forms?,

(2) What are the key elements or concepts focused on in the classroom, and

(3) What resources does the art teacher use to teach about these art forms? and

(4) How does the art teacher's understanding and valuing of particular aspects of objects transfer to the students' own knowledge and understanding of art outside their own cultures? Referring back to Clarks' statement about the role of art teachers in presenting art from diverse cultures to students, a pertinent question worth asking is are art teachers "engineering" only positive reactions to art from unfamiliar cultures? These are all questions I was curious about as I began my study.

\section{Methodology}

Semi-structured interviews, document analysis, and observation were the methods I used to collect my data. Ms. Nelson ${ }^{1}$ was selected based on her experience as an art teacher, enthusiasm for art education, her interest and experience in teaching students about art forms of non-western cultures, and her gender and her Euro-American roots. The three students who participated in this study were selected by the art teacher, based upon her classroom experience with the students and their willingness to be interviewed about their understanding of Northwest Coast art. Initially, I spent several class periods observing Ms. Nelson and her sixth grade art class. As a basis for the interviews with Ms. Nelson, I developed an interview protocol which consisted of thirteen questions. Depending on responses from the art teacher, the order the questions asked varied from the organized protocol and in some instances alternative questions were raised. Student interviews were conducted at the beginning of the unit of study and later at the end of the unit. On two separate

\footnotetext{
' A fictitious name has been used in order to ensure confidentiality of the art teacher
} 
occasions I interviewed Ms. Nelson, two sixth grade girls, and one sixth grade boy.

I conducted an analysis of documents used by Ms. Nelson to introduce her students to Northwest Coast designs. A scholarly book used to prepare for the unit of study was referred to during the time the she taught the unit. The book served as Ms. Nelsons' main resource for preparing for this unit of study. A written unit plan was requested, but initially, one did not exist. The art teacher stated that she had not actually written up her plans for the unit, but would be happy to do so if I supplied her with a form, which I eventually did. The students' final art products were analyzed to see if parallels existed between the student's art work, comments made by the teacher during her introduction to the unit, and the visuals she used in class. Data collected from the interviews were analyzed using content analysis, (Gordon, 1978; Holsti, 1969; Mostyn, 1985) to determine the evolution of the students' knowledge and understanding of Northwest Coast iconography.

A video taped interview with a Haida carver, Mr. Miller ${ }^{2}$ served as my data source, which I transcribed and analyzed as my source of a native interpretation of the iconography of a Haida totem pole. The actual interview was conducted by an art teacher who visited the area during the summer of 1995 and interviewed three Northwest Coast Native American artists about their art. These interviews were not shown to student participants in the pilot study. In addition, scholarly writings on Northwest Coast art and design were analyzed for support or discrepancies between Ms. Nelson's and Mr. Miller's interpretation and valuing of Northwest Coast art.

\section{Ethical Concerns and Subjectivity}

Consent forms were provided for Ms. Nelson and the three students who participated in the study. Interview transcripts were made available for confirmation of data. My request for a written unit of study plan and Ms. Nelson's subsequent response raised ethical concerns for me, but securing a unit of study plan served as valuable data for my research. My desire to represent all subjects who participated in the study in a fair and balanced manner remained throughout my research. I was particularly sensitive towards recognition of my Euro-American cultural heritage and limited understanding of Northwest Coast art. I attempted to address my concerns by looking at video tapes, books, exhibition catalogues, and by attending a workshop held for art educators on Northwest Coast art.

\section{Assertions}

Ms. Nelson introduced the unit of study through a brief lecture where she discussed Northwest Coast iconography in a general way. Terminology like ovid and S Form, and the names of three major Northwest Native groups, the Haida, Tlinglit, and Nootka were written on the chalkboard prior to the students' arrival. The colors red, black, yellow, and green were written on the chalkboard and

\footnotetext{
${ }^{2} \mathrm{~A}$ fictitious name has been used in order to ensure confidentiality of the Haida carver.
}

Marilyn Zurmuehlen's Working Papers In Art Education 1996-1997 
identified as typical colors used by Northwest Coast peoples. Ms. Nelson told students that Northwest Coast Native Americans revered animals and that many of their designs represented animals like ravens or whales. Ms. Nelson also explained that Native American designs from the Northwest Coast were symmetrical. She then asked for volunteers who remembered the term symmetrical from a previous lesson to reiterate the definition for the rest of the class. After a student explained that symmetry meant a design was the same on both sides, Ms. Nelson elaborated. A brief discussion about colors typically used by the Northwest Coast followed. Ms. Nelson explained to students that red, yellow, green, and in some cases blue-green were used. Ms. Nelson told her students that black was often used as a unifying color. Ms. Nelson also told her students that the sources for creating these colors initially came various minerals, which were prepared along with saliva. The students then were given black and white copies of Northwest Coast designs illustrated by scholars and a few color photographs of art work produced by Northwest Coast Native Americans.

The students listened intently during the introduction to the unit of study and to the directions for their studio project. The children were told that they were to draw an animal design in the style of the Northwest Coast that was represented in the visuals they had just seen or they could modify the designs in some way. After drawing their designs, students were told to outline them using black crayon and to fill in the interior spaces using colored tempera paint. After beginning their project, some students asked Ms. Nelson for help in the selection of designs and what colors to paint their designs.

Through my observations and interviews with the three sixth grade students and analyses of the interview with Mr. Miller, themes emerged which were categorized as (1) students viewed Ms. Nelson as an authority figure; (2) study of Northwest Coast art revolved around formal qualities; (3) students' understanding of Northwest Coast design and aesthetic forms was severely limited due to the approach used by the art teacher and (4) although Mr. Miller recognized formal qualities within Haida totem poles, his interpretative comments reflected an integration of both formal and contextual aspects of his carving. These themes now will be discussed in detail.

It became clear that Ms. Nelson was viewed by students as an authority figure, who provided credibility to the knowledge and visuals she presented. Students readily used the photographs and photo copies of Northwest Coast art to copy and in a few cases to create modified designs. One student explained, "The art teacher's presentation about Northwest Coast art was very helpful. She talked to us about the designs and symmetry and all of that. Her talk helped me to make my design like the Native Americans."

The students' finished art work reflected the art teacher's understanding and aesthetic valuing of Northwest Coast design. Analysis of the completed painted designs made by the students revealed a visual replay of the Ms. Nelson's interpretation of Northwest Coast designs and the formal qualities, which she emphasized throughout the unit. No additional time was provided for further exploration of the Northwest Coast culture and its aesthetic forms by

Marilyn Zurmuehlen's Working Papers In Art Education 1996-1997 
students. Attempts to explore Northwest Coast art as an integral part of the social, political, and cultural context of Northwest Coast society were purposely by-passed due to Ms. Nelson's belief that the information would not benetit the students. There was no evidence that attempts were made to integrate the art unit with other subjects in the general curriculum, with the exception that Ms. Nelson stated that her students had studied the Mayan Indians just prior to this unit and she indicated that she hope the students remembered some of the things they discussed during the unit. If relationships existed between Mayan art and Northwest Coast art, no attempts were made to formally address these relationships with the class.

The students' understanding of Northwest Coast design and aesthetic forms was severely limited due to the approach used by the art teacher. Ms. Nelson stated that she believed elementary level students required more "hands on" art experiences and that she felt their ability to digest contextual information was minimal. She also indicated that although she initiated the unit of study due to a personal experience, there was not adequate planning time or financial support for developing these kinds of unit of study. In addition, Ms. Nelson indicated through my interviews with her that she was unable to attend the state art education conference which included workshops on Northwest Coast art. She also did not mention searching sources like ERIC data base for pertinent information, nor did she identify any recent art education publications. Ms. Neison did mention on several occasions an interest in checking Dover Publications (an educational publication company which produces resource materials for teachers) which she had heard had produced something about Northwest Coast art. The biggest obstacle to further investigation of educational and resource material was available time according to Ms. Nelson

Although Mr. Miller, the Haida carver recognized formal elements within Haida totem pole designs, his understanding and valuing of Haida designs were integrated within a contextual framework. Mr. Miller took great care in describing the various pole types and their functions like the mortuary pole, the commemorative pole, and the ridicule pole. A good deal of time was devoted to telling the Haida myth called "Wasco" whose characters were depicted in the pole he was carving at the time of his interview. The interview with Mr. Miller stands in stark contrast to Ms. Nelson's approach to discussing the Northwest Coast iconography with her students. Ms. Nelson did mention that many of the forms depicted in the visuals used in class were associated with Northwest Coast myths, however her statement came towards the latter part of the unit of study.

Exploration of specific myths, therefore, was presented as an afterthought and occurred during the latter part of the unit. Ms. Nelson did not identify specific myths and their relationship to the design motifs found in many of the totem poles.

The value of the cultures' design and form was discussed only through its formal qualities, qualities believed to inherent within the objects. No attempts were made to have students explore the objects' functions as a determination of value, or as intricately connected to the value placed on the iconography by Native Americans. A statement made by Ms. Nelson during one of my in-class 
observations reflects the decontextual approach used during the unit of study and her continued emphasis on formal qualities, "Northwest Coast designs were exhibited or actually painted on buildings or totem poles and we will stack our designs to look like a totem pole when we are finished."

\section{Conclusions}

This study reveals implications for in-service education of art teachers, and the accessibility to exemplary multicultural teaching resource materials, but perhaps more importantly, this study emphasizes the need for cross-cultural dialogues about art from diverse cultures. The face of American classrooms continue to experience dramatic changes while the representation of minority teachers within the field of art education have experienced minimal changes. Preservice Euro-American art teachers or those already in the field in many cases have not been educated about American subcultures and their arts or about nonWestern art. If we wish to avoid oversimplification of complex cultures, art educators must be willing to do research and present more in-depth art lessons that integrate formal and contextual information together instead of teaching the two as separate entities. A more anthropological approach in the teaching of art is called for. Art teachers must be willing to exam their own beliefs and attitudes about art and culture, and aesthetic systems of other cultures is necessary in order to expand their focus beyond a Western "fine art" point of view in the classroom. Calliope's Sisters: A Comparative Study Of Philosophies Of Art, by Anderson (1990) is an example of such an attempt. Otherwise art teachers will continue to engage students in meaningless activities which do little to make students literate about non-Western art or Western art. Hamblen (1990) explained:

the creation of cardboard box totem poles, plaster of Paris Greek drama masks, and paper confetti Byzantine mosaics will probably not contribute much toward the development of multiple cultural literacies, let alone a critical consciousness of contrasting aesthetic and social value systems. (p. 224)

\section{REFERENCES}

Andersdon, R. (1990). Calliope's sisters: A comparative study of philosophies of art. New Jersey: Prentice Hall.

Armstrong, C. (1990). Teaching art in a multicultural/multiethnic society. In B. Young, (Ed.), Art, culture, and ethnicity (pp. 97-113). Reston, VA: National Art Education Association.

Blandy, D. \& Congdon, K. (1989). Art in a democ acy. New York: Teachurs College

Congdon, K. (1989). Multi-Cultural approaches to art criticism. Studies in Art Education, 30 (3), 176-184.

Marilyn Zurmuehlen's Working Papers In Art Education 1996-1997 
Chalmers, G. (1992). D.B.A.E. as multicultural education. Art Education,45 (3), 16-24.

Clark, G. (1990). Art in the schizophrenic fast lane: A response. Art Education, 43(6), 8-23.

Depillars, M. (1990). Multiculturalism in visual arts education: Are we ready for multiculturalism? in B. Young (Ed.), Art, cutture, and ethnicity ( $p p$ 125-133). Reston, VA: National Art Education Association

Feest, C. F. (1992). (rev, ed.). Native arts of North America. New York: Thames and Hudson.

Gordon, W.I. (1978). Communication: Personal and public. New York: Alfred.

Hart, L. (1990). Aesthetic pluralism and multicultural art education. Studies in Art Education, 32 (3), 145-159.

Hamblen, K. (1990). Beyond the aesthetic of the cash-culture literacy. Studies in Art Education, 31 (4), 216-225.

Holm, B. (1987). Spirit and ancestor. Seattle: University of Washington Press.

Holsti, O.R. (1969). Content analysis for the social sciences and humanities. Reading, MA: Addison.

Loeb, B. (1990). Indigenous art of the northwest coast. In B., Young (Ed.). A rt, culture, and ethnicity (pp. 15-31). Reston, VA: National Art Education Association.

Mariahazy, J. (1990). Multiculturalism and art education. In B. Young (Ed.), A rt, culture and ethnicity. (pp. 193-200). Reston, VA: National Art Education Association.

McFee, J. (1991). Art education progress: A field of dichotomies or a network of mutual support. Studies in Art Education,32(2), 70-82.

Mostyn, B. (1985). The content analysis of qualitative research data: A dynamic approach. In M. Brenner, J. Brown, \& D. Canter (Eds.), The research interview: Uses and approaches ( $p p .115-145$ ). London: Academic Press.

Neperud, R. \& Stuhr, P. (1993). Cross-cultural valuing of Wisconsin Indian $\mathrm{c}$ t by Indians and non-Indians. Studies in Art Education, 34 (4), 244-253.

Smith, P. (1994). Multicultural issues: Dilemmas and hopes. Art Education, 47 (4), 13-17.

Marilyn Zurmuehlen's Working Papers In Art Education 1996-1997 
Sahasrabudhe, P. (1992). Multicultural art education: A proposal for curriculum content, structure and attitudinal understandings. Art

Education,45(3), 41-47.

Stewart, H. (1979). Looking at Indiana art of the Northwest coast. Seattle: University of Washington Press.

Stuhr, P. (1994). Multicultural art education and social reconstruction. Studies in Art Education, 35 (3), 171-178.

Stuhr, P. , Petrovich-Mwaniki, L. \& Wasson, R. (1992). Curriculum guidelines for the multicultural art classroom. Art Education, 45 (1).

Zimmerman, E. (1990). Questions ałout multiculture and art education or "I'll never forget the day M'blawi stumbled on the work of the PostImpressionists." Art Education,43 (6), 8-24. 